\title{
AMORPHOUS STRUCTURE IN CU-Zn-V-AI OXIDE COMPOSITE CATALYST FOR METHANOL REFORMING
}

\author{
MOHd SABri MAHMUd ${ }^{1 *}$, ZAHIRA YAAKOB ${ }^{2}$, AbU BAKAR MOHAMAD $^{3}$, WAN \\ RAMLI WAN DAUD ${ }^{4}$ AND Vo NGUYEN DAI VIET ${ }^{5}$ \\ ${ }^{1,5}$ Faculty of Chemical \& Natural Resources Engineering, \\ Universiti Malaysia Pahang, Lebuhraya Tun Razak, \\ 26300 Kuantan, Pahang, Malaysia. \\ 2, 3, 4 Department of Chemical \& Process Engineering, \\ Faculty of Engineering and Built Environment, \\ Universiti Kebangsaan Malaysia, 43600 Bangi, Selangor, Malaysia. \\ "Corresponding author: mohdsabri@ump.edu.my
}

(Received: $18^{\text {th }}$ Feb 2017; Accepted: $30^{\text {th }}$ Dec 2017; Published on-line: $1^{\text {st }}$ June 2018)

https://doi.org/10.31436/iiumej.v19i1.808

\begin{abstract}
Cu}-\mathrm{Zn}-\mathrm{V}-\mathrm{Al}$ oxide composite catalysts were prepared using a coprecipitation method to investigate hydrogen and carbon monoxide yield of a methanol reforming reaction. The mass compositions of metals were initially determined on the Simplex Centroid statistical design. The effects of various metal compositions on the physicochemical properties of the catalyst were studied via X-ray diffractogram (XRD), temperature-programmed reduction (TPR) analyses, and reaction. XRD revealed crystals in the samples. Crystalline $\mathrm{CuO}$ in $\mathrm{Cu}_{30} \mathrm{~V}_{30} \mathrm{Al}_{40}$ formed with the addition of zinc oxide at the metal loading below $30 \mathrm{wt} \%$. A combination of zinc oxide and vanadia, however, had no $\mathrm{Zn}-\mathrm{V}$ complex crystal but its scanning electron microscopy image showed the formation of string structures (AS). The catalyst that contained the AS exhibited a broad hydrogen reduction peak in the TPR analysis. Vanadium at a loading below $40 \mathrm{wt} \%$ with various zinc and cuprum compositions also formed small ASs and exhibited single TPR peaks. A reaction yield study revealed the optimum compositions of metal oxides when the data was fitted by response surface plots. The catalysts with high content of AS were not at the peaks however. $\mathrm{Cu}-\mathrm{Zn}$ based catalysts showed the highest hydrogen yield for the reaction temperature of between $150{ }^{\circ} \mathrm{C}$ to $225^{\circ} \mathrm{C}$ and vanadia-promoted catalyst with AS only appeared to be the optimum catalyst at the higher temperature.
\end{abstract}

ABSTRAK: Mangkin komposit oksida $\mathrm{Cu}-\mathrm{Zn}-\mathrm{V}-\mathrm{Al}$ disediakan menggunakan kaedah pemendakan bersama untuk mengkaji hasil hidrogen dan karbon monoksida daripada tindak balas pembentukan semula metanol. Komposisi jisim logam-logam dikenal pasti terlebih dahulu menggunakan reka bentuk statistik Simplex Centroid. Pelbagai kesan komposisi logam terhadap sifat-sifat mangkin kimia-fizikal dikaji menerusi analisisanalisis pembelauan sinar-X (XRD) dan program penurunan suhu teratur (TPR), dan tindak balas kimia. Hasil analisis XRD menzahirkan kristal pada sampel-sampel. Hablur $\mathrm{CuO}$ terbentuk dalam $\mathrm{Cu}_{30} \mathrm{~V}_{30} \mathrm{Al}_{40}$ dengan penambahan zink oksida pada muatan logam kurang daripada $30 \%$ berat. Gabungan zink oksida dan vanadia walau bagaimanapun tidak menghasilkan hablur kompleks $\mathrm{Zn}-\mathrm{V}$, namun imbasan imej mikroskop elektron menunjukkan pembentukan struktur tetali (AS). Mangkin yang mengandungi AS menunjukkan penurunan puncak hidrogen yang lebar dalam analisis TPR. Vanadium pada muatan berat logam kurang daripada $40 \%$ berbanding komposisi zink dan kuprum juga membentuk AS kecil dan menghasilkan puncak-puncak TPR tunggal. Hasil tindak balas 
kajian menunjukkan komposisi optimum oksida logam apabila data ujikaji dipadankan dengan menggunakan plot permukaan respon. Mangkin yang mempunyai kandungan AS tertinggi bagaimanapun tidak berada pada puncak. Mangkin berasaskan $\mathrm{Cu}-\mathrm{Zn}$ menunjukkan hasil hidrogen tertinggi bagi suhu tindak balas antara $150{ }^{\circ} \mathrm{C}$ hingga $225^{\circ} \mathrm{C}$ dan mangkin yang ditambah vanadia bersama AS pula muncul sebagai mangkin optimum pada suhu lebih tinggi.

KEYWORDS: $C u-Z n-V-A l$; methanol reforming; autothermal; amorphous; string; fuel cell

\section{INTRODUCTION}

Proton exchange membrane fuel cell (PEMFC) is an attractive alternative to the conventional power generators using coal and petroleum. Hydrogen, as the fuel for PEMFC, reacts with oxygen from air on highly-sensitive Pt-impregnated electrolyte membranes to produce electricity. A resource with high hydrogen selectivity and minimum $\mathrm{CO}$ level is required to ensure a sufficient and clean supply to the fuel cell, especially for on-board purposes.

Catalytic steam reforming of methanol (SRM) as shown in Eq. (1) is a favourable method of hydrogen production since its resource is abundantly available from oil and gas industries.

$$
\mathrm{CH}_{3} \mathrm{OH}+\mathrm{H}_{2} \mathrm{O} \stackrel{\text { catalyst }}{\longrightarrow} \mathrm{CO}_{2}+3 \mathrm{H}_{2}
$$

A Cu-based catalyst is usually employed in the synthesis of hydrogen from methanol. The co-precipitated $\mathrm{Cu}-\mathrm{Zn}$-Al oxide catalyst was mostly studied in the SRM reaction as it showed high activity and hydrogen selectivity at the temperature range from $200{ }^{\circ} \mathrm{C}$ to 320 ${ }^{\circ} \mathrm{C}$ [1]. Energy consumption of the endothermic reaction of SRM, which is $131 \mathrm{~kJ} \mathrm{~mol}^{-1}$, is considerably high and an additional energy supply is required if it is for on-board use.

Many metal oxides such as nickel [2], zirconium [1], cobalt, and chromium [3] were promoted to investigate the potential of autothermal reforming of methanol (ATRM), the reaction that combines SRM with partial oxidation of methanol as shown in Eq. (2). Although the net heat of the reactions decreased, the selectivity of carbon dioxide (byproduct) to carbon monoxide dropped to below $95 \%$ when the reaction temperature was raised higher than the reaction temperature of $220{ }^{\circ} \mathrm{C}$ at adiabatic conditions. The carbon monoxide formation via the decomposition reaction shown in Eq. (3) can be poison to the catalyst of reformers and PEMFC, and necessitates regeneration [4]. A new metal promoter is therefore required to reduce the $\mathrm{CO}$ selectivity.

$$
\begin{aligned}
& \mathrm{CH}_{3} \mathrm{OH}+1 / 2 \mathrm{O}_{2} \stackrel{\text { catalyst }}{\longrightarrow} \mathrm{CO}_{2}+2 \mathrm{H}_{2} \\
& \mathrm{CH}_{3} \mathrm{OH} \stackrel{\text { catalyst }}{\longrightarrow} \mathrm{CO}+2 \mathrm{H}_{2}
\end{aligned}
$$

Among other transition metals, vanadium oxide (vanadia) has a good track record in most oil, gas, and petrochemical industries. It possesses a moderately-oxidizing catalyst property to the dehydrogenation and partial oxidation reaction of hydrocarbons and alcohols to form alkenes [5]. Besides the good selectivity, its physical structure is also strong to support other catalysts and thus render better longevity.

In this study, cuprum nitrate and vanadium oxytrichloride were co-precipitated with zinc and aluminium nitrate to form a $\mathrm{Cu}-\mathrm{Zn}-\mathrm{V}-\mathrm{Al}$ oxide composite catalyst. The calcined catalysts of $\mathrm{Cu}-\mathrm{Zn}-\mathrm{V}-\mathrm{Al}$ oxides from various combinations were characterized using X-Ray 
Diffraction (XRD), Temperature Programmed Reduction (TPR), and Scanning Electron Micrograph (SEM) methods. In the XRD analysis, crystal was determined and accordingly compared with SEM images. Well-dispersed cuprum oxide crystal was usually shown by small peak and was favourable for high selectivity catalysts [6]. The lowest reduction temperature that corresponds to the activity of catalyst for SRM was determined from TPR analysis [7]. Alumina as the support in crystal form is favourable for high thermal resistance and low catalyst sintering [8]. The catalysts activity in hydrogen via SRM and auto thermal reforming of methanol (ATRM) reaction were finally tested in order to delineate the selectivity of hydrogen and carbon monoxide.

\section{EXPERIMENTAL}

Methanol, anhydrous nitrates of cuprum, zinc and aluminium, vanadium oxytrichlorides, and sodium carbonate were supplied by Fluka Chemie AG with the purity greater than 98.95\%. 99.95\% Argon, 99.995\% Nitrogen and 99.995\% hydrogen gases were supplied by Malaysian Oxygen (MOX) and standard gas from Perkin Elmer for catalyst reduction and analysis.

Similar to the work conducted by Lima et al. [9], metal compositions mixed were initially determined using the statistical mixture design method namely, Simplex Centroid, with the aid of the Design Expert ${ }^{\circ} 6$ software. The compositions of metals, $\mathrm{Cu}, \mathrm{Zn}$ and $\mathrm{V}$ based on mass (Fig. 1), were varied based on the Scheffe model in a ternary diagram where BET surface area, the lowest reduction temperature, the hydrogen yield and the reaction temperature responded according to either quadratic or cubic equations, depending on the fitness of the surface response plot as generally expressed in Eq. (4). The subscript at the end of each metal acronym signifies their respective mass percentage. Al was inactive in SRM or ATRM reaction as proven in the preliminary blank tests. The Al ratio was fixed to $40 \%$ by mass out of other metals, imitated from the best composition $\left(\mathrm{Cu}_{30} \mathrm{Zn}_{30} \mathrm{Al}_{40}\right)$ of the catalyst that had the lowest $\mathrm{CO}$ formation and cuprum sintering $[6,10]$.

$$
\begin{aligned}
& 1^{*}=\mathrm{Cu}_{60} \mathrm{Al}_{40} \\
& 2 *=\mathrm{Zn}_{60} \mathrm{Al}_{40} \\
& 3 *=\mathrm{V}_{60} \mathrm{Al}_{40} \\
& 4=\mathrm{Cu}_{30} \mathrm{Zn}_{30} \mathrm{Al}_{40} \\
& 5=\mathrm{Zn}_{30} \mathrm{~V}_{30} \mathrm{Al}_{40} \\
& 6=\mathrm{Cu}_{30} \mathrm{~V}_{30} \mathrm{Al}_{40} \\
& 7 *=\mathrm{Cu}_{40} \mathrm{Zn}_{10} \mathrm{~V}_{10} \mathrm{Al}_{40} \\
& 8=\mathrm{Cu}_{10} \mathrm{Zn}_{40} \mathrm{~V}_{10} \mathrm{Al}_{40} \\
& 9=\mathrm{Cu}_{10} \mathrm{Zn}_{10} \mathrm{~V}_{40} \mathrm{Al}_{40} \\
& 10=\mathrm{Cu}_{20} \mathrm{Zn}_{20} \mathrm{~V}_{20} \mathrm{Al}_{40}
\end{aligned}
$$

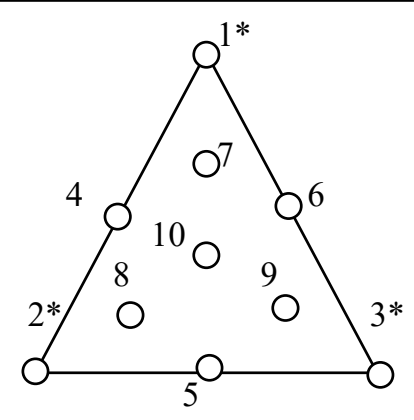

Fig. 1: Simplex Centroid Design on metal mass composition. Starred numbers denote the replicated samples.

$$
E(Y)=\sum_{i=1}^{q} \beta_{i} x_{i}+\sum_{i=1}^{q} \sum_{j=i+1}^{q} \beta_{i j} x_{i} x_{j}+\sum_{i=1}^{q} \sum_{j=i+1}^{q} \sum_{k=j+1}^{q} \beta_{i j k} x_{i} x_{j} x_{k}
$$

Co-precipitated $\mathrm{Cu}-\mathrm{Zn}-\mathrm{V}-\mathrm{Al}$ oxide catalysts were prepared according to the method proposed by Begum [11]. A $200 \mathrm{ml}$ aqueous mixture of $\mathrm{VOCl}_{3}$ and $\mathrm{Cu}, \mathrm{Zn}$ and $\mathrm{Al}$ nitrates were precipitated by 1.1 of required stoichiometry of $\mathrm{Na}_{2} \mathrm{CO}_{3}$. Reactions that occurred in the precipitation may be expressed as in Eqs. (5) and (6). 


$$
\begin{aligned}
p \mathrm{VOCl}_{3}(\mathrm{l})+2 p \mathrm{Na}_{2} \mathrm{CO}_{3}(\mathrm{aq})+[\mathrm{Cu}, \mathrm{Zn}, \mathrm{Al}]\left(\mathrm{NO}_{3}\right)_{p}(\mathrm{aq}) \rightarrow 3 p \mathrm{NaCl}(\mathrm{aq})+2 p \mathrm{CO}_{2}(\mathrm{~g}) \\
+p \mathrm{NaNO}_{3}(\mathrm{aq})+[\mathrm{Cu}, \mathrm{Zn}, \mathrm{Al}]\left(\mathrm{VO}_{3}\right)_{p}(\mathrm{~s}) \\
q[\mathrm{Cu}, \mathrm{Zn}, \mathrm{Al}]\left(\mathrm{NO}_{3}\right)_{p}(\mathrm{aq})+r \mathrm{Na}_{2} \mathrm{CO}_{3}(\mathrm{aq}) \rightarrow q p \mathrm{NaNO}_{3}(\mathrm{aq})+\left[\mathrm{Cu}, \mathrm{Zn}, \mathrm{Al}_{q}\right]_{q}\left(\mathrm{CO}_{3}\right)_{r}(\mathrm{~s})
\end{aligned}
$$

where $p, q$, and $r$ are stoichiometry coefficients.

Vanadium salt and aluminium nitrate tended to create an acidic environment in the mixing that had a detrimental effect on the chemical bonding of metal oxides and alumina. Thus, $\mathrm{pH}$ was maintained around 7 to 8 under vigorous stirring at room temperature $\left(28^{\circ} \mathrm{C}\right)$ using sodium carbonate. The resulting sludge was washed with deionized water at least thrice and was dried at $100-120^{\circ} \mathrm{C}$ in a ventilated oven overnight, prior to crushing. Finally, the dry sludge powder was calcined at $500{ }^{\circ} \mathrm{C}$ for $3 \mathrm{hrs}$ in the furnace while blanketed with pure nitrogen.

Catalyst samples at around $250-400 \mu \mathrm{m}$ in particle size were used in each characterization and reaction study. Crystallinity of each 1-g sample was characterized using the SIEMENS X-Ray diffractometer (D5000) within the angle range of $2^{\circ}$ to $60^{\circ}$. Species phases of the signal peak were identified according to the international diffraction data library.

TPR characterization for the weight range from 800 to $900 \mathrm{mg}$ of each sample was carried out using the Altamira Instrument 200 apparatus, which was equipped with a thermal conductivity detector (TCD). All samples were initially treated by flowing argon at $120{ }^{\circ} \mathrm{C}$ for $1 \mathrm{hr}$ prior to flowing $5 \% \mathrm{H}_{2}$ in $\mathrm{Ar}$ at the temperature range of 50 to $600{ }^{\circ} \mathrm{C}$. The signal from the TCD was interpreted by referring the average of at least 10 pulses of the same amount and ratio of feed into a calibrated volume $(526 \mu \mathrm{l})$ of spiral tube.

The surface metal compositions of the calcined samples were scanned and mapped using the LEO-1450VP electron microscope equipped with energy dispersive X-ray (SEMEDX) and were integrated in the Inca ${ }^{\odot}$ software. The gold-coated samples were scanned within 1000, 10,000 and 15,000 times of magnification. The electron beam accelerated at $12 \mathrm{kV}$ to the coated sample in a vacuum space from various angles and the reflection was then collected by a probe within a distance of 9 to $13 \mathrm{~mm}$ from the sample. Although the metal topography was measured, the results will not be discussed in detail here.

Each $500 \mathrm{mg}$-calcined catalyst was tested in a stainless steel tubular reactor with 5-mm diameter in an automated system developed by Zeton Altamira [12] using the automation software, LabView ${ }^{\odot}$. After the catalyst was pre-heated and reduced at $150^{\circ} \mathrm{C}$ in a nitrogenhydrogen flow, methanol $(\mathrm{MeOH})$ was fed through at $0.5 \mathrm{ml} / \mathrm{hr}$ along with air and steam at the ratios of $\mathrm{H}_{2} \mathrm{O}: \mathrm{MeOH}:=1.3: 1$ (for both $\mathrm{SRM}$ and $\mathrm{ATRM}$ ) and $\mathrm{O}_{2}: \mathrm{MeOH}=0.2: 1$ (ATRM) at $150{ }^{\circ} \mathrm{C}, 200{ }^{\circ} \mathrm{C}, 250{ }^{\circ} \mathrm{C}$ and $300{ }^{\circ} \mathrm{C}$ as similarly tested by Agrell and co-authors $[13,14]$ and inlet pressure allowable from 1 to $2 \mathrm{~atm}$. The reformate effluent, at the steady state, was then analysed using an online Perkin Elmer gas chromatograph (GC). During the analysis, the reformate was carried along with $\mathrm{He}$ after a gas mixer to three stages of sequence by using auto-switching multichannel valves so that various gaseous product components such as hydrogen, carbon dioxide, carbon monoxide, water, methanol, oxygen, methane, acetylene, ethane and ethylene could be measured separately through pack columns using a thermal conductivity detector (TCD) and a flame ionization detector (FID). The GC was calibrated with a standard gas of all components prior to the analysis. 


\section{RESULTS AND DISCUSSION}

The characterizations of the prepared catalyst were conducted after calcination and the same fresh catalyst samples were subsequently employed in the reaction study. The replications used in the study were as per proposed in the experimental design. SEM-EDX results as shown in Fig. 6 proved that all mixed metals were in the prepared sample at the same composition.

\subsection{Catalyst Characterizations}

\subsubsection{X-Ray Diffraction and Scanning Electron Micrograph with Energy-Dispersed X-Ray}

Ten samples were analysed using the XRD and SEM methods. Crystallinity of metals was identified from the diffractograms within the $2 \theta$ angle spanning from $0^{\circ}$ to $60^{\circ}$ as depicted in Fig. 2, Fig. 4, and Fig. 7. The intervals for the intensity axis and the angle axis are uniform at all diffractograms. The sharpness and height of peaks qualitatively exhibit the size and concentration of particular crystals according to Debye-Scherrer equation (Eq. (7)).

$$
\tau=\frac{k \lambda}{\beta \cos \theta}
$$

where $\tau$ is the crystal size, $\lambda$ is the wavelength of the $\mathrm{x}$-ray radiation, $k$ is the shape factor, $\beta$ is the line width at half maximum height and $\theta$ is the angular position of the peak maximum [15]. Sharper and higher peaks will indicate more distinguished and greater crystals and vice versa but the wellness of active metal distribution on a support that is usually attributed to dumb and small diffractogram peaks enhances the activity of the catalyst [15]. However, discussion of XRD patterns in this study is qualitative because of the limitation of the software that analysed the diffractogram without estimation of $\beta$.

Fig. 2 shows the catalyst samples for single metal oxide with alumina. $\mathrm{CuO}$ peaks are clearly seen in the $\mathrm{Cu}_{60} \mathrm{Al}_{40}$ sample in Fig. 2(a) at $38.8^{\circ}$ and $35.48^{\circ}$ similarly obtained by Begum [11]. For $60 \%$ loading of cuprum, the $\mathrm{CuO}$ was probably not well distributed. This evidence is supported by the micrographic images in Fig. 3(a) and (b) where a dark mass of $\mathrm{CuO}$ formed separately from a whitish mass of alumina. There is a $\mathrm{Cu}_{2}(\mathrm{OH})_{2} \mathrm{CO}_{3}$ peak at $49^{\circ}$ [11], clearly indicating a small crystal. The X-ray diffraction of the $\mathrm{Zn}_{60} \mathrm{Al}_{40}$ sample revealed the distinctive peak of $\mathrm{ZnAl}_{2} \mathrm{O}_{4}$ at $36.8^{\circ}$ in Fig. 2(b). This might imply a large crystal of $\mathrm{ZnAl}_{2} \mathrm{O}_{4}$ as also seen from the micrographic images in Fig. 3(c) and (d). However, neither aluminium nor zinc crystals, nor their combinations, could be easily distinguished as their colours in the image are fairly similar. Three small and broad alumina peaks at $43^{\circ}, 53^{\circ}$, and $58^{\circ}$ [16] similarly indicate the small and well-dispersed alumina crystals. Fig. 2(d) shows an interesting diffractogram of the $\mathrm{V}_{60} \mathrm{Al}_{40}$ catalyst. Appearing at many angles such as $16.1^{\circ}, 21.0^{\circ}, 24.0^{\circ}, 26.8^{\circ}, 31.5^{\circ}, 33.0^{\circ}, 34.1^{\circ}, 42.0^{\circ}$, and $51.6^{\circ}$, the $\mathrm{V}_{2} \mathrm{O}_{5}$ peaks spike at various sharpness and sizes while $\mathrm{AlV}_{3} \mathrm{O}_{9}$ peaks were at $26^{\circ}$ and $56.7^{\circ}$ [17]. SEM images in Fig. 3 (g) and (h) clearly confirm the appearance of crystal structures that look like coral. Two types of pore, of $1 \mu \mathrm{m}$ and $0.1 \mu \mathrm{m}$ in diameter, can be seen in Fig. 3 (e) and (f), respectively. 


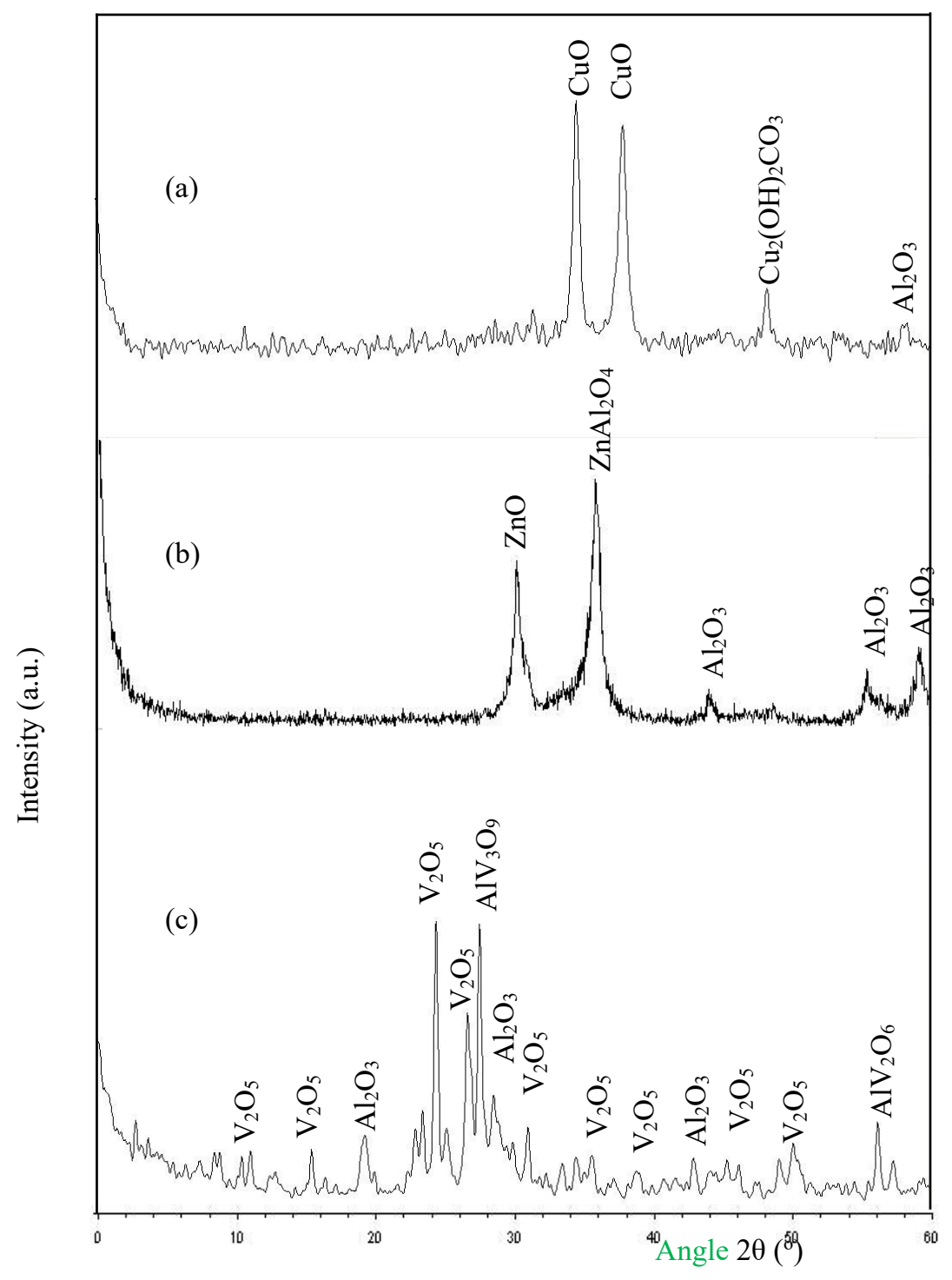

Fig. 2: XRD diffractograms of the catalyst samples

(a) $\mathrm{Cu}_{60} \mathrm{Al}_{40}$ oxides, (b) $\mathrm{Zn}_{60} \mathrm{Al}_{40}$ oxides and (c) $\mathrm{V}_{60} \mathrm{Al}_{40}$ oxides.

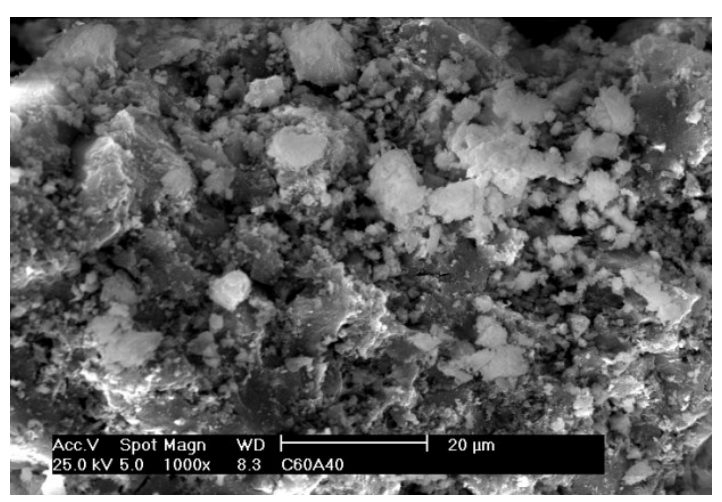

(a)

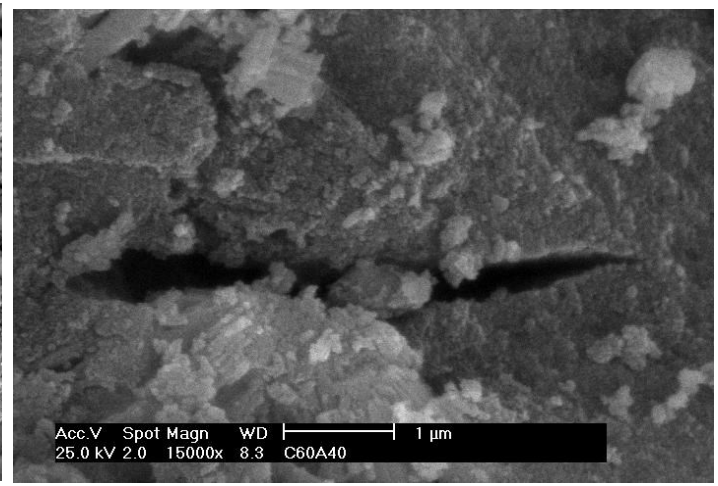

(c) 


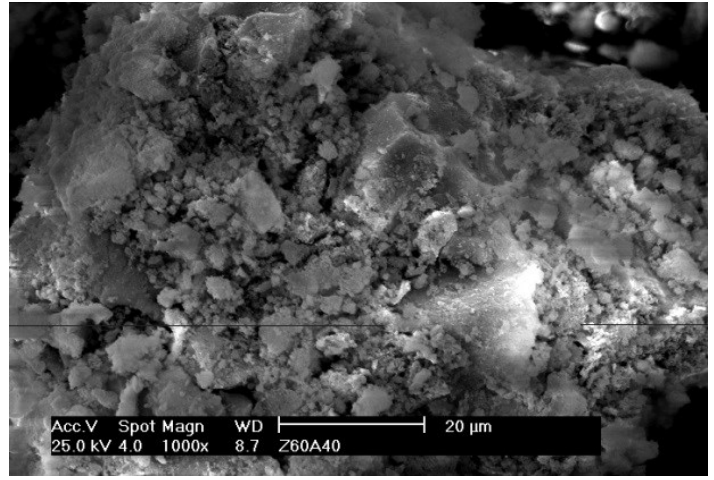

(c)

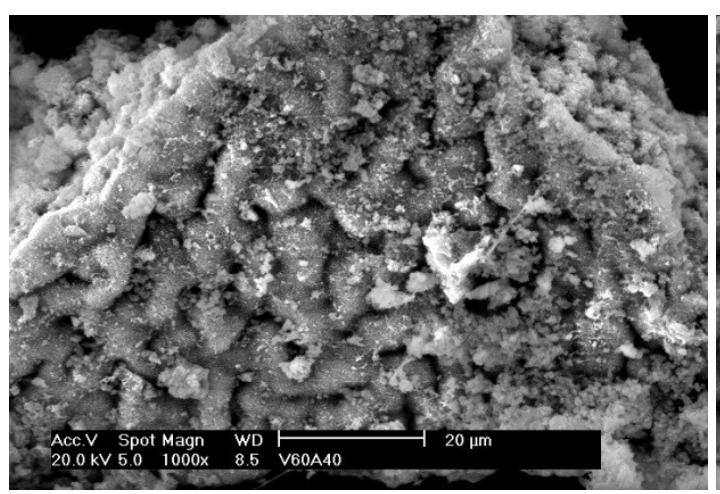

(e)

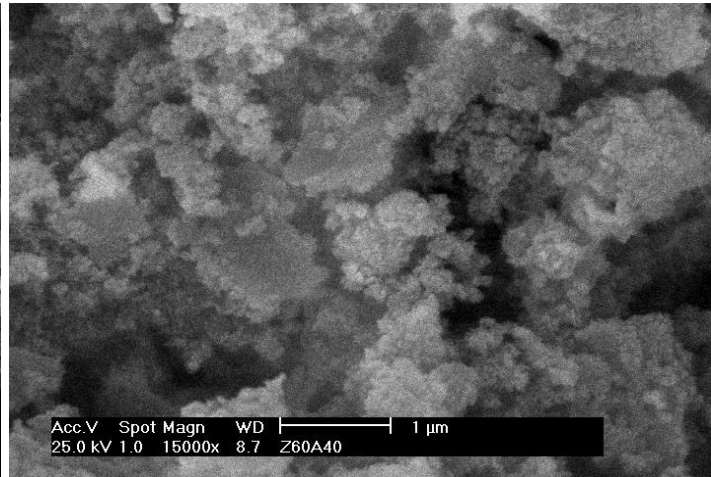

(d)

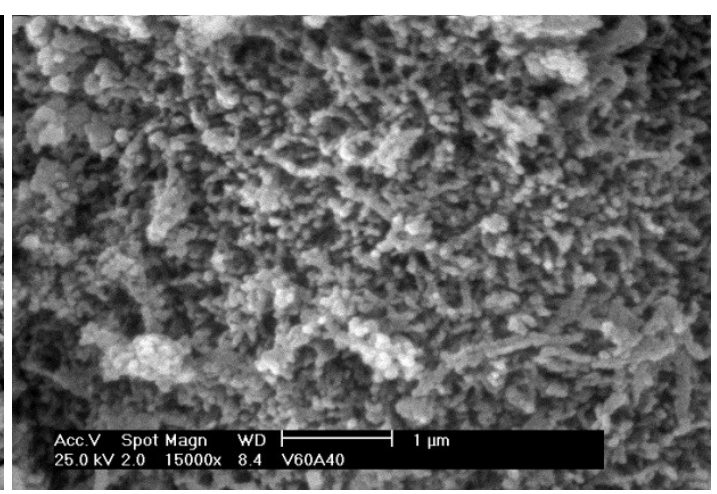

(f)

Fig. 3: Micrographs for the bi-metal co-precipitated catalysts at 2 magnifications:

(a) $\mathrm{Zn}_{30} \mathrm{Al}_{40}$ at 1000 times, (b) $\mathrm{Cu}_{60} \mathrm{Al}_{40}$ at 15000 times, (c) $\mathrm{Zn}_{60} \mathrm{Al}_{40}$ at 1000 times, (d) $\mathrm{Zn}_{60} \mathrm{Al}_{40}$ at 15000 times, (e) $\mathrm{V}_{60} \mathrm{Al}_{40}$ at 1000 times and (f) $\mathrm{V}_{60} \mathrm{Al}_{40}$ at 15000 times.

Diffractograms of two-metal-oxide precipitations with alumina at the same ratio are shown in Fig. 4. The XRD analysis of the $\mathrm{Cu}_{30} \mathrm{Zn}_{30} \mathrm{Al}_{40}$ sample, as depicted in Fig. 4(a), resulted in two predominant peaks of zinc and three broad peaks of alumina. However, no peak of cuprum or its oxides appeared in combination with zinc suggesting that their crystals dispersed well and were small in size [1]. The micrographic image in Fig. 5(a) shows the structure of the $\mathrm{Cu}_{30} \mathrm{Zn}_{30} \mathrm{Al}_{40}$ sample at $10 \mathrm{~K}$ magnification. Fig. 4(b) depicts the diffractogram for the catalyst mixture of cuprum, vanadium, and aluminium. The numerous peaks of vanadia that appeared in the previous $\mathrm{V}$-Al oxide catalyst became only two in $\mathrm{Cu}_{30} \mathrm{~V}_{30} \mathrm{Al}_{40}$, appearing at $14.2^{\circ}$ and $23^{\circ}$ due to the addition of cuprum at the same mass ratio. Cuprum crystal peaks in this diagram appeared at the same angle to the $\mathrm{CuO}$ one with smaller sizes suggesting dispersion action by vanadia on the crystals. A small $\mathrm{AlV}_{3} \mathrm{O}_{9}$ peak appeared between $25-27^{\circ}$ similar to what was reported by Reddy and Varma [17] who prepared vanadia-alumina catalysts by impregnating a vanadium precursor onto $\gamma$-alumina. The alumina peak was not present. Its micrograph image shows very little crystal, as can be seen in Fig. 5(b). In the $\mathrm{Zn}_{30} \mathrm{~V}_{30} \mathrm{Al}_{40}$ diffractogram of Fig. 4(c), zinc crystals might not disperse with the addition of vanadia as the peak characteristics of zinc oxide and zinc oxidealumina remains relatively similar to Fig. 2(b) seen previously. Although the peaks of vanadia were fewer, no combined $\mathrm{Zn}-\mathrm{V}$ crystal was detected. However, the trio-combination of zinc, vanadium and aluminium might create an amorphous structure, since no crystal appeared for this form. Fig. 5 (c-i), (c-ii), and (c-iii) depict images of the SEM of the catalyst at $10 \mathrm{~K}, 15 \mathrm{~K}$, and $1 \mathrm{~K}$ magnification, respectively. Whitish strings were among the catalyst crystals. 
The result of the spectrum from the energy-dispersed X-ray scan in Fig. 6 shows no evidence of unknown species. Thus, the amorphous structure was a combination of the metals, most likely zinc and vanadium.

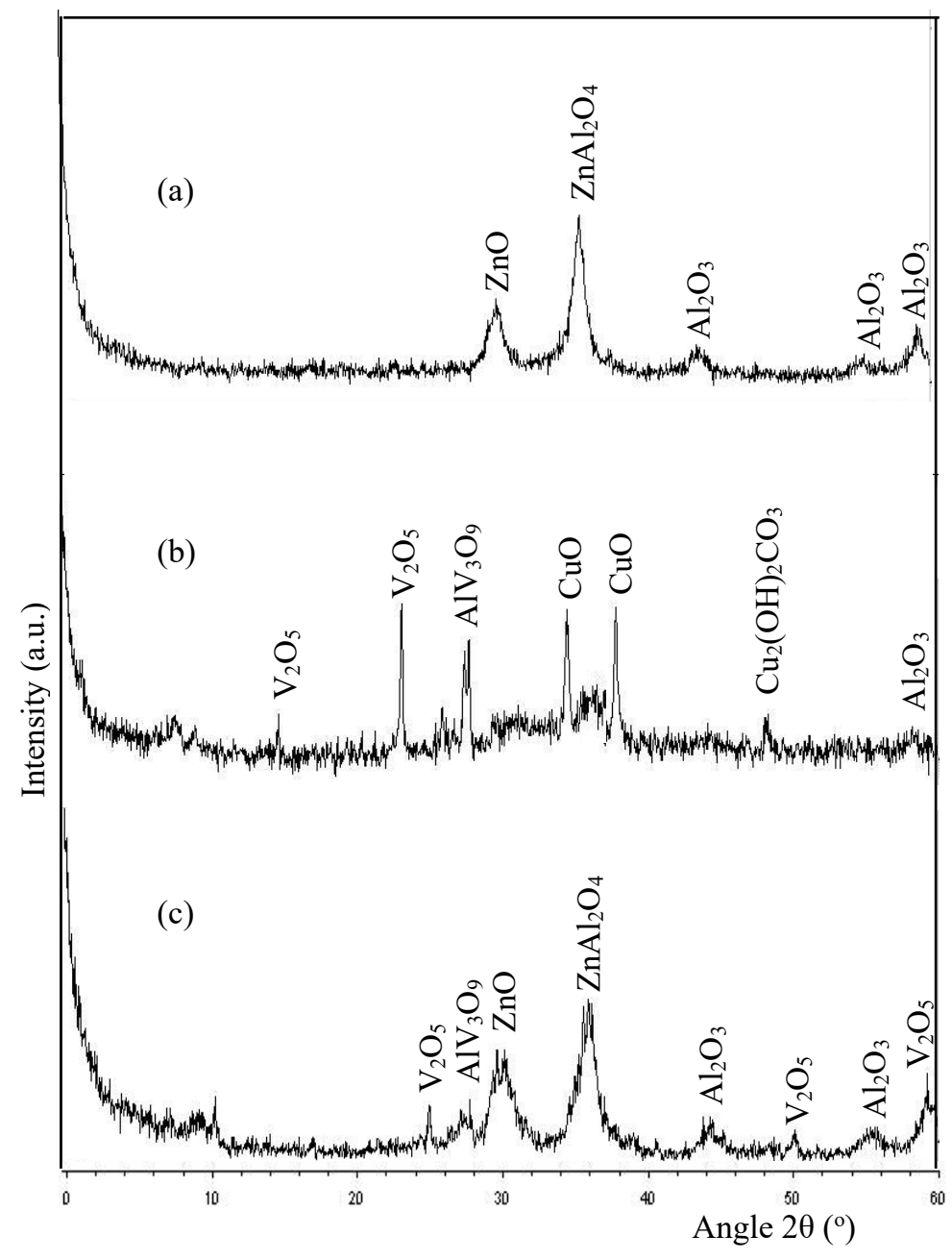

Fig. 4: XRD diffractograms of the catalyst samples (a) $\mathrm{Cu}_{30} \mathrm{Zn}_{30} \mathrm{Al}_{40}$ oxides, (b) $\mathrm{Cu}_{30} \mathrm{~V}_{30} \mathrm{Al}_{40}$ oxides and (c) $\mathrm{Zn}_{30} \mathrm{~V}_{30} \mathrm{Al}_{40}$ oxides.

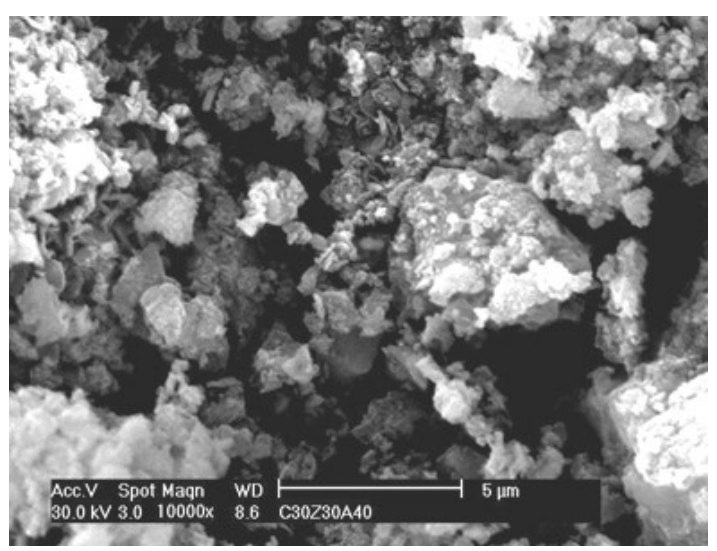

(a)

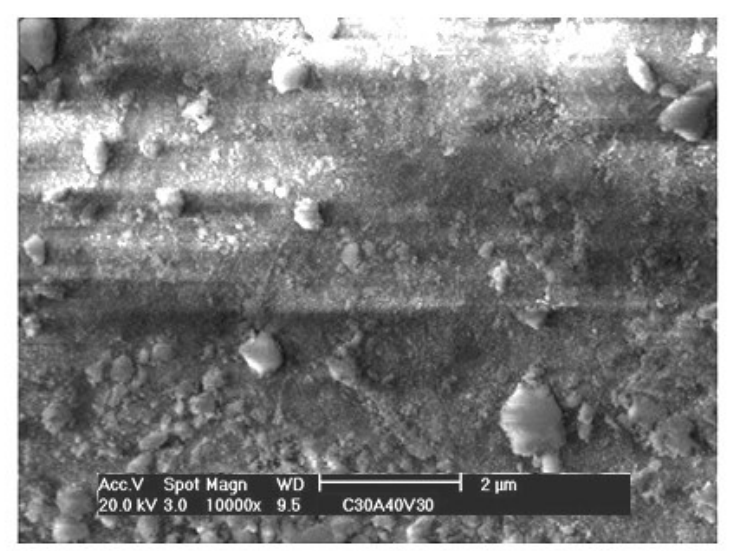

(b) 


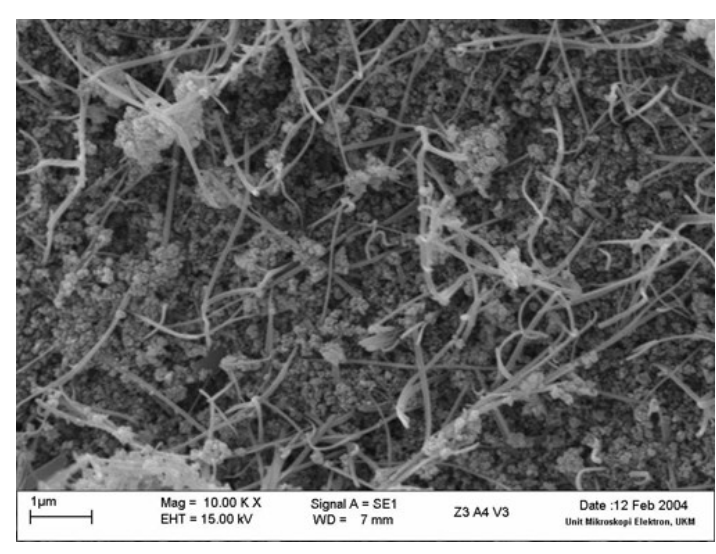

(c-i)

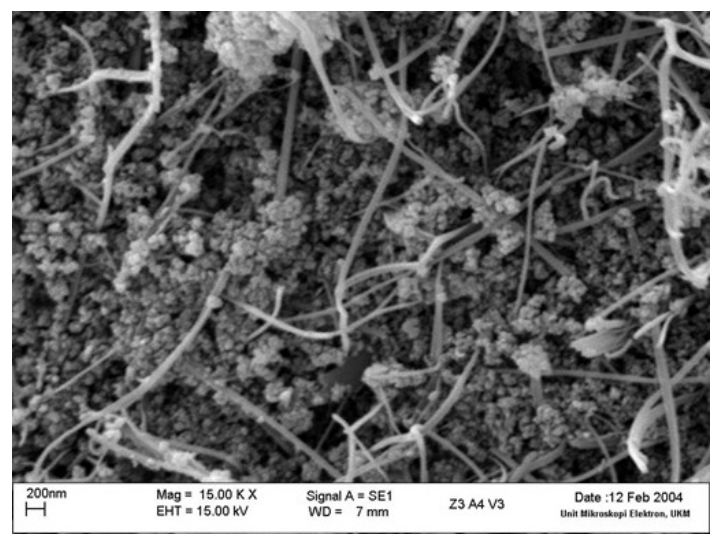

(c-ii)

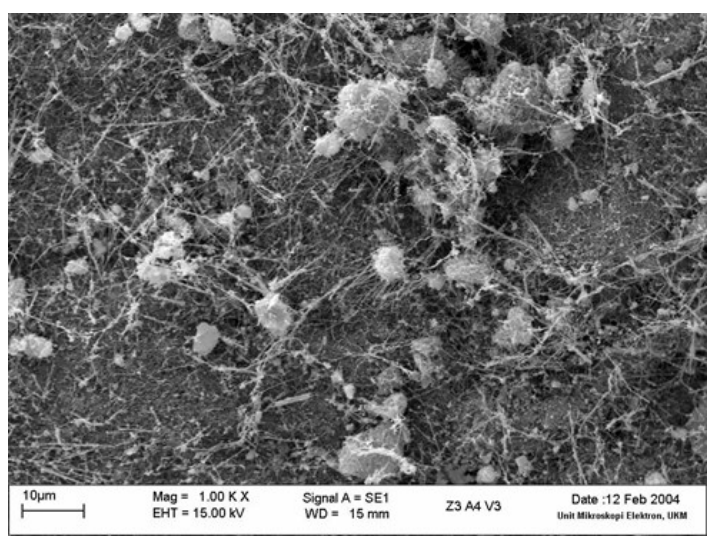

(c-iii)

Fig. 5: Micrographs of tri-metal co-precipitated catalyst at various magnifications:

(a) $\mathrm{Cu}_{30} \mathrm{Zn}_{30} \mathrm{Al}_{40}$ at 10000 times, (b) $\mathrm{Cu}_{30} \mathrm{~V}_{30} \mathrm{Al}_{40}$ at 10000 times and

(c) $\mathrm{Zn}_{30} \mathrm{~V}_{30} \mathrm{Al}_{40}$ at (c-i) 10000 times, (c-ii) 15000 times and (c-iii) 1000 times.

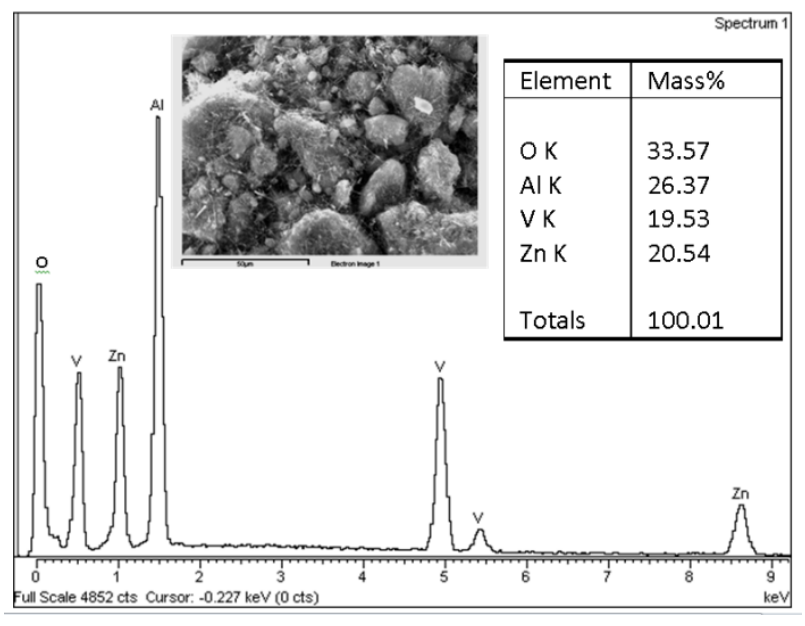

Fig. 6: Scanned image with energy dispersed X-ray confirmed that no other material appeared in the catalyst and the composition of the catalyst was approximately same as initial mixing.

Diffractograms of tri-metal co-precipitation with alumina are summarised in Fig. 7. No clear crystal was detected in the $\mathrm{Cu}_{40} \mathrm{Zn}_{10} \mathrm{~V}_{10} \mathrm{Al}_{40}$ sample, as seen in Fig. 7(a). In Fig. 7(b), 
the $\mathrm{Cu}_{10} \mathrm{Zn}_{40} \mathrm{~V}_{10} \mathrm{Al}_{40}$ diffractogram followed a similar trend to the peaks of $\mathrm{ZnO}$ and $\mathrm{ZnAl}_{2} \mathrm{O}_{4}$ crystals nearly disappeared. As for the $\mathrm{Cu}_{10} \mathrm{Zn}_{10} \mathrm{~V}_{40} \mathrm{Al}_{40}$ 's diffractogram in Fig. 7(c), besides $\mathrm{ZnAl}_{2} \mathrm{O}_{4}$ and $\mathrm{Al}_{2} \mathrm{O}_{3}$, vanadia and vanadium-aluminium oxide crystals were also detected with the sharp and small peaks indicating that the crystals were probably formed as individual crystals and were small. Rod-looking structure that was probably similar to previous amorphous structure and whitish mass attributed to alumina and/or zinc oxides, as suggested earlier, were clearly appeared in Fig. 8(c) and (d). Although vanadia and V-Al crystals were not seen at the $\mathrm{Cu}_{20} \mathrm{Zn}_{20} \mathrm{~V}_{20} \mathrm{Al}_{40}$ sample where only zinc-aluminium oxide crystals appeared, alumina and cuprum oxide appeared as depicted in Fig. 7(d), and they were evidenced in the micrograph images of Fig. 8(e) and (f).

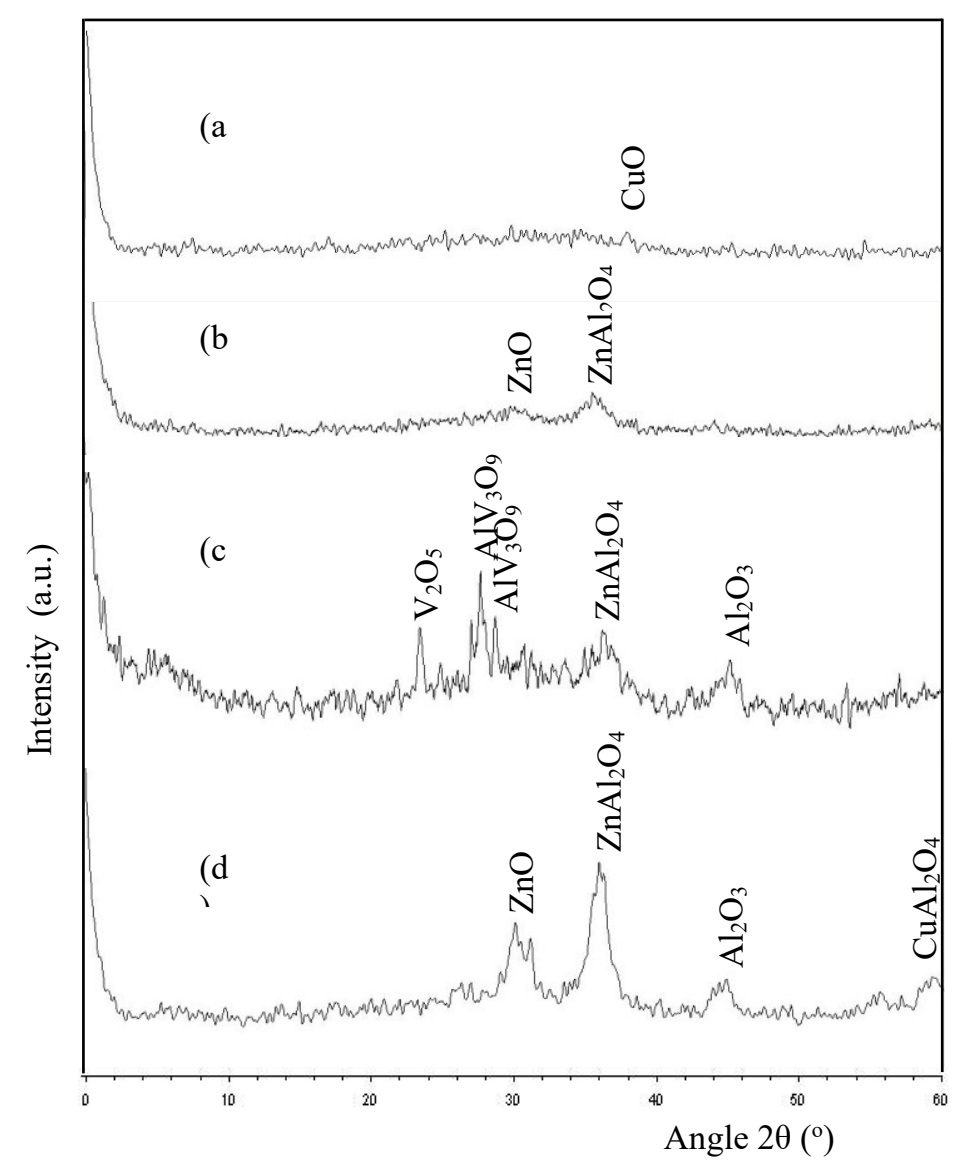

Fig. 7: XRD diffractograms of the catalyst samples (a) $\mathrm{Cu}_{40} \mathrm{Zn}_{10} \mathrm{~V}_{10} \mathrm{Al}_{40}$ oxides (b) $\mathrm{Cu}_{10} \mathrm{Zn}_{40} \mathrm{~V}_{10} \mathrm{Al}_{40}$ oxides (c) $\mathrm{Cu}_{10} \mathrm{Zn}_{10} \mathrm{~V}_{40} \mathrm{Al}_{40}$ oxides and (d) $\mathrm{Cu}_{20} \mathrm{Zn}_{20} \mathrm{~V}_{20} \mathrm{Al}_{40}$ oxides.
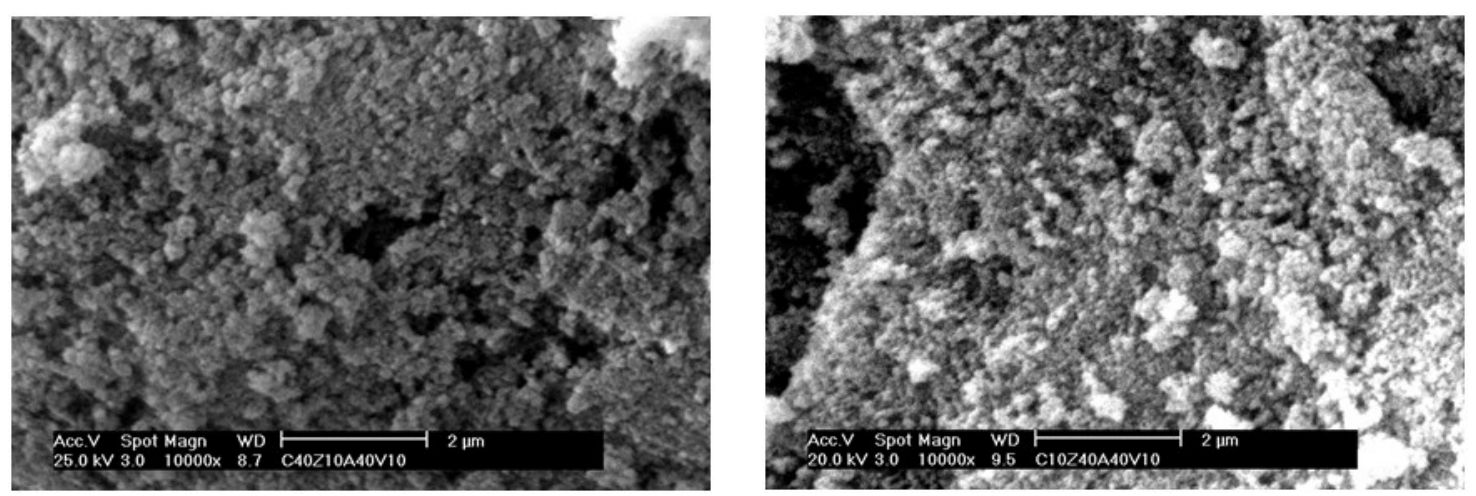
(a)

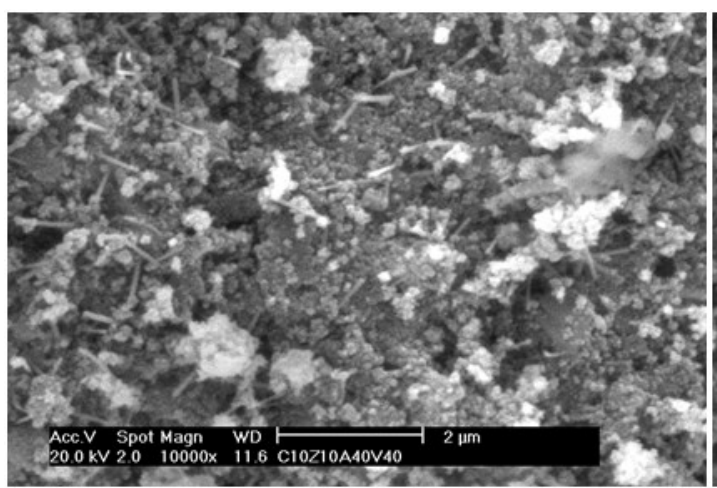

(c)

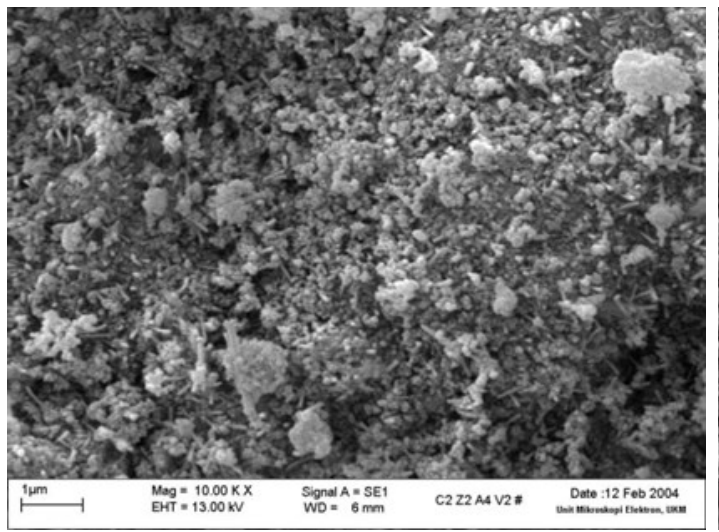

(e) (b)

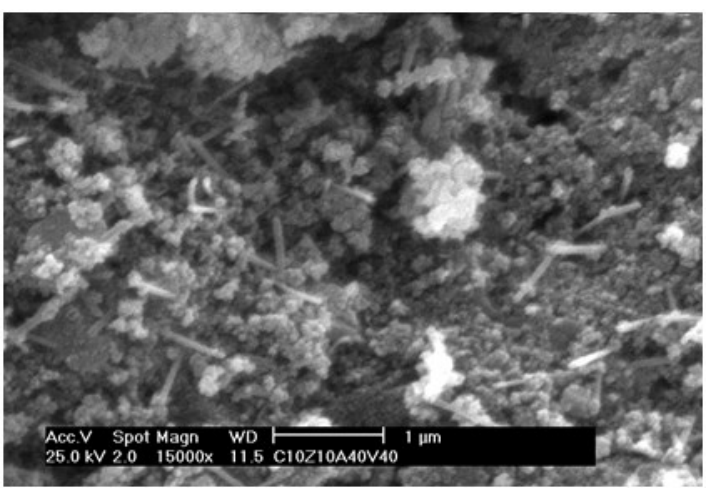

(d)

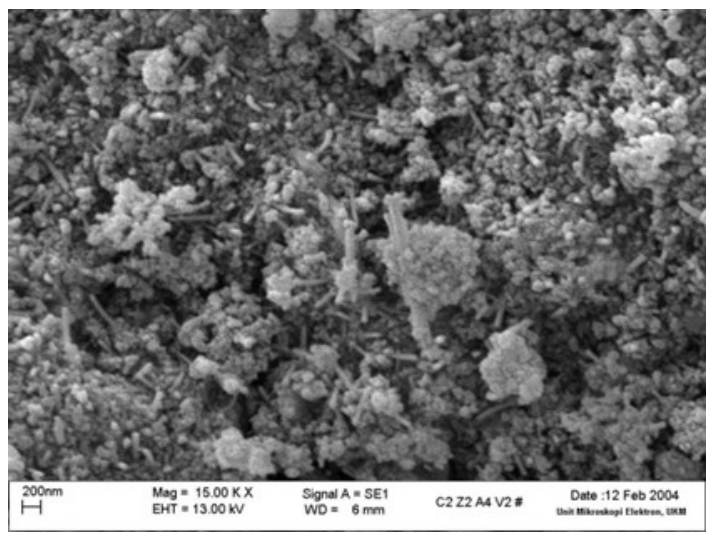

(f)

Fig. 8: Micrographs of four-metal co-precipitated catalysts at various magnifications:

(a) $\mathrm{Cu}_{40} \mathrm{Zn}_{10} \mathrm{~V}_{10} \mathrm{Al}_{40}$ at 10000 times, (b) $\mathrm{Cu}_{10} \mathrm{Zn}_{40} \mathrm{~V}_{10} \mathrm{Al}_{40}$ at 10000 times,

(c) $\mathrm{Cu}_{10} \mathrm{Zn}_{10} \mathrm{~V}_{40} \mathrm{Al}_{40}$ at 1000 times, (d) $\mathrm{Cu}_{10} \mathrm{Zn}_{10} \mathrm{~V}_{40} \mathrm{Al}_{40}$ at 15000 times,

(e) $\mathrm{Cu}_{20} \mathrm{Zn}_{20} \mathrm{~V}_{20} \mathrm{Al}_{40}$ at 10000 times and (d) $\mathrm{Cu}_{20} \mathrm{Zn}_{20} \mathrm{~V}_{20} \mathrm{Al}_{40}$ at 15000 times.

\subsubsection{Temperature Programmed Reduction}

The activity of oxide metal species in the calcined catalyst was observed from the TPR analysis spanning from $50{ }^{\circ} \mathrm{C}$ to $630{ }^{\circ} \mathrm{C}$ as illustrated in Fig. 9. $\mathrm{Cu}_{60} \mathrm{Al}_{40}$ and $\mathrm{V}_{60} \mathrm{Al}_{40}$ runs exhibit the reduction in temperature at a minimum of $278^{\circ} \mathrm{C}$ and above $600{ }^{\circ} \mathrm{C}$ respectively. $\mathrm{Cu}_{60} \mathrm{Al}_{40}$ TPR shows two broad peaks that may be attributed to the stepwise reduction of cuprum oxide $\left(\mathrm{Cu}^{2+} \rightarrow \mathrm{Cu}^{+} \rightarrow \mathrm{Cu}^{0}\right)$ [18]. $\mathrm{Zn}$-Al could not be reduced at all observed temperatures since both are more electropositive than hydrogen. As discussed in diffractogram results, the $\mathrm{Zn}$ addition enhanced $\mathrm{Cu}$ crystal dispersion on alumina [8, 14] and as a result, this effect decreased the reduction temperature of the $\mathrm{Cu}$-based catalyst [19] as exhibited by $\mathrm{Cu}_{40} \mathrm{Zn}_{10} \mathrm{~V}_{10} \mathrm{Al}_{40}$ and $\mathrm{Cu}_{30} \mathrm{Zn}_{30} \mathrm{Al}_{40}$ trends. Inversely, the addition of $\mathrm{V}$ increased the reduction temperature and this might be due to the high reduction temperature of vanadia as exhibited by $\mathrm{Cu}_{10} \mathrm{Zn}_{10} \mathrm{~V}_{40} \mathrm{Al}_{40}$ and $\mathrm{Cu}_{30} \mathrm{~V}_{30} \mathrm{Al}_{40}$ trends. Similarly, the $\mathrm{Cu}_{20} \mathrm{Zn}_{20} \mathrm{~V}_{20} \mathrm{Al}_{40}$ reduction exhibits slightly higher temperature than the $\mathrm{Cu}_{40} \mathrm{Zn}_{10} \mathrm{~V}_{10} \mathrm{Al}_{40}$. The loading of vanadium seemed to start increasing the reduction temperature between $10 \%$ and $20 \%$ which might be $20 \%$ lower than reported by K. Inumaru et al. [20], who prepared $\mathrm{V}$-Al using an incipient wetness impregnation method. $\mathrm{V}_{60} \mathrm{Al}_{40}$ or with the lower cuprum 
loading $\left(\mathrm{Cu}_{10} \mathrm{Zn}_{40} \mathrm{~V}_{10} \mathrm{Al}_{40}\right.$ and $\left.\mathrm{Cu}_{10} \mathrm{Zn}_{10} \mathrm{~V}_{40} \mathrm{Al}_{40}\right)$ exhibits two peaks, which are most-likely attributed to the stepwise reduction of vanadia $\left(\mathrm{V}_{2} \mathrm{O}_{5} \rightarrow \mathrm{VO}_{2} \rightarrow \mathrm{V}_{2} \mathrm{O}_{3}\right)$ as reported by Botto, Vassallo [21]. In general, a low loading vanadia (below 40\%) exhibits the single tall peak that reveals the prefect combination by giving a single reduction characteristic.

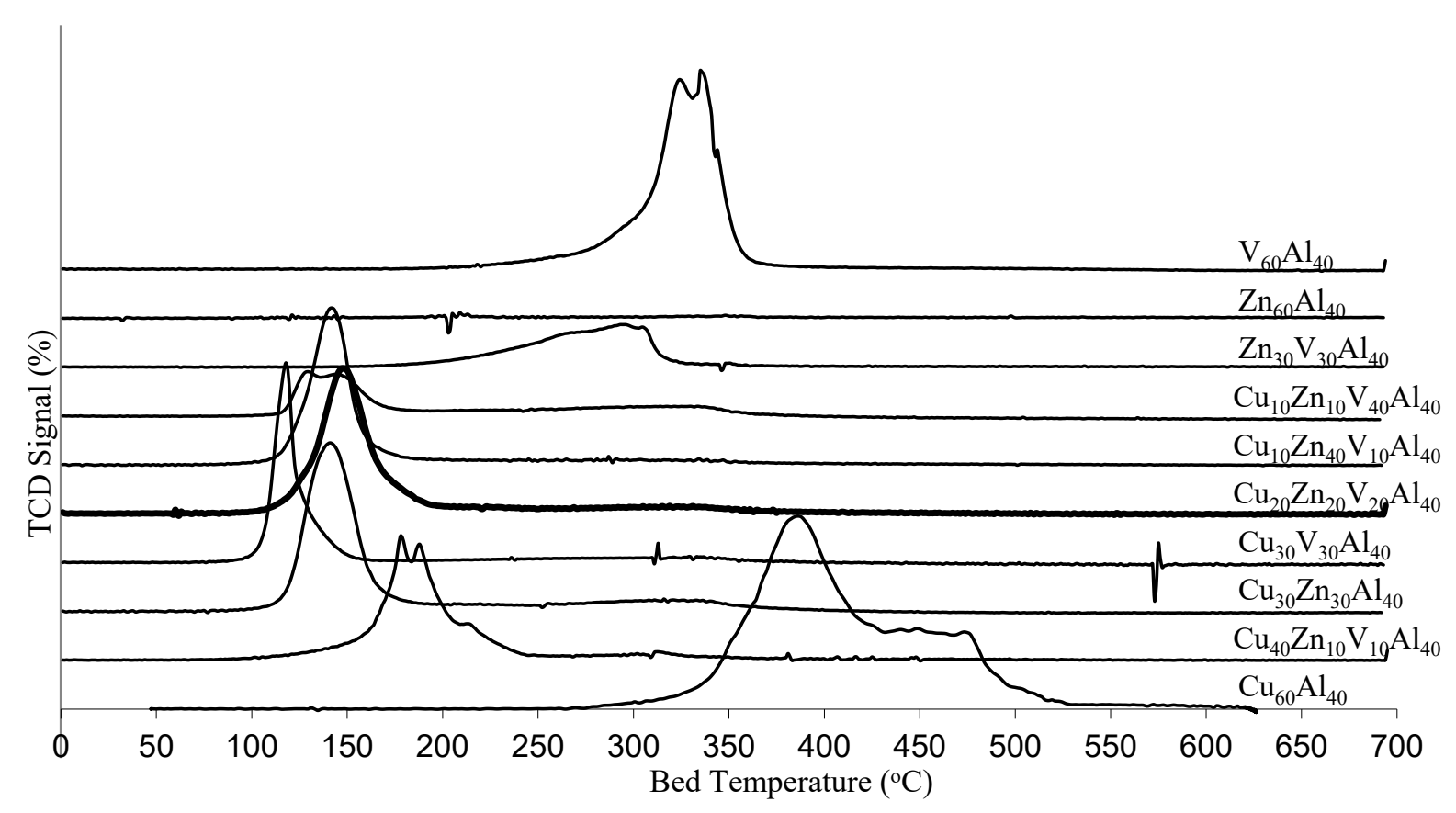

Fig. 9: TPR results for the prepared catalyst.

\subsection{Reaction Yield Study}

The catalysts were tested in a methanol reforming reaction, both SRM and ATRM, at temperatures ranging from $150{ }^{\circ} \mathrm{C}$ to $300^{\circ} \mathrm{C}$ in order to obtain optimum metal compositions. The same samples were employed from one temperature to other temperatures. The hydrogen and CO yields, $Y_{H_{2}}$ and $Y_{C O}$ respectively, at steady state, were calculated according to Eqs. (8) and (9), respectively, the normalised version of Choi and Stenger's [22].

$$
\begin{gathered}
Y_{H_{2}}=\frac{F_{H_{2}}}{2 F_{M 0}} \times 100 \% \\
Y_{C O}=\frac{F_{C O}}{F_{M 0}} \times 100 \%
\end{gathered}
$$

where $F_{H 2}, F_{M 0}$ and $F_{M}$ are flows of hydrogen, fed methanol, and unconverted methanol, respectively. The normalisation is based on the stoichiometry of the steam reforming reaction that produces 3 moles of hydrogen for each mole of methanol converted.

\subsubsection{Steam Reforming of Methanol (SRM)}

The plot of the hydrogen yield against reaction temperature is depicted in

Fig. 10. The reference catalyst, $\mathrm{Cu}_{30} \mathrm{Zn}_{30} \mathrm{Al}_{40}$ shows high activity from $150{ }^{\circ} \mathrm{C}$ to 225 ${ }^{\circ} \mathrm{C}$. However, from $250{ }^{\circ} \mathrm{C}$ to $300{ }^{\circ} \mathrm{C}$, the reaction yields of the catalysts promoted with 
vanadium are gradually prominent. This is consistent with the result of low TPR shown before.

The change of the maximum yield is clear when it is plotted against the composition of catalyst metals using the response surface method. The Scheffe model was used to fit data and the significance of their fitness was confirmed using the ANOVA analyses. The plots were stacked as can be seen in Fig. 11. Initially, the peak appears at the $\mathrm{Cu}-\mathrm{Zn}-\mathrm{Al}$ catalyst. This peak apparently moves towards the region of metal composition that contains vanadia and it is sustained until $300^{\circ} \mathrm{C}$. Catalyst samples with AS that had a high vanadium loading of $40 \mathrm{wt} \%$ were not optimal. The optimum catalyst compositions in Fig. 11 at the respective reaction temperatures are summarised in Table 1.

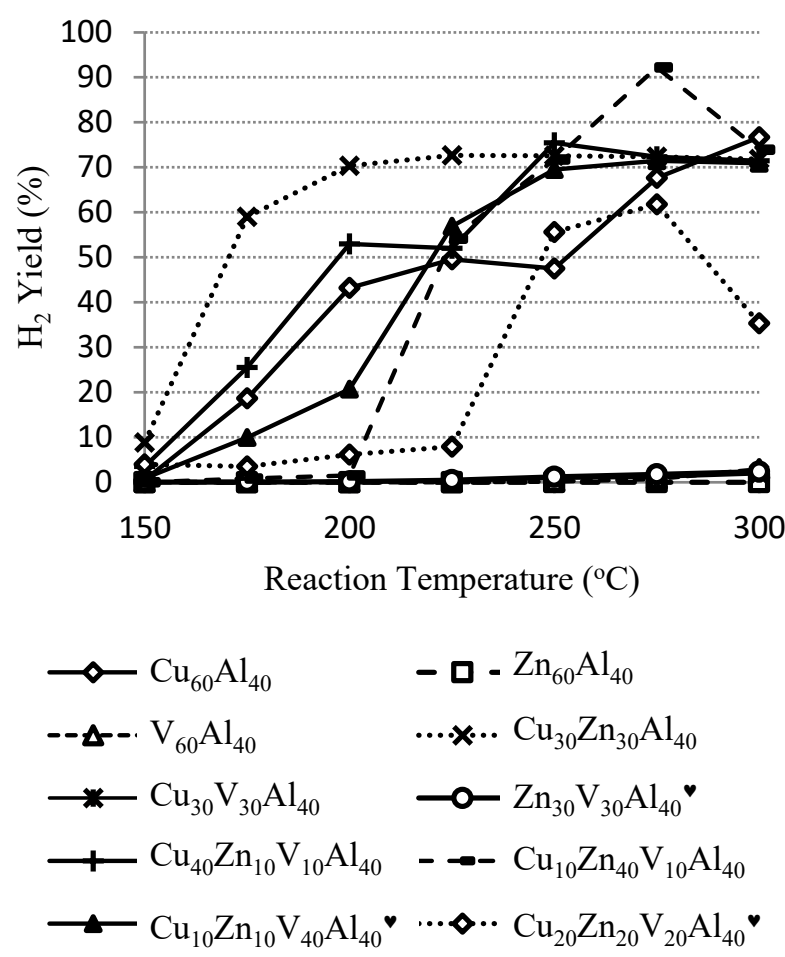

Fig. 10: Hydrogen yield versus reaction temperature at the steady state SRM process for various catalysts. The catalyst legends added with superscript to denote having an amorphous structure.

Table 1: Optimum mixture of catalysts in SRM

\begin{tabular}{clc}
\hline Reaction Temperature $\left({ }^{\circ} \mathbf{C}\right)$ & Catalyst & Hydrogen Yield (\%) \\
\hline 150 & $\mathrm{Cu}_{34.2} \mathrm{Zn}_{25.8} \mathrm{Al}_{40}$ & 6.85 \\
175 & $\mathrm{Cu}_{36.0} \mathrm{Zn}_{24.0} \mathrm{Al}_{40}$ & 35.32 \\
200 & $\mathrm{Cu}_{39.6} \mathrm{Zn}_{19.8} \mathrm{~V}_{0.6} \mathrm{Al}_{40}$ & 70.68 \\
225 & $\mathrm{Cu}_{37.2} \mathrm{Zn}_{22.2} \mathrm{~V}_{0.6} \mathrm{Al}_{40}$ & 73.45 \\
250 & $\mathrm{Cu}_{28.2} \mathrm{Zn}_{21.6} \mathrm{~V}_{12.6} \mathrm{Al}_{40}$ & 86.62 \\
275 & $\mathrm{Cu}_{26.4} \mathrm{Zn}_{25.8} \mathrm{~V}_{9.6} \mathrm{Al}_{40}$ & 96.88 \\
300 & $\mathrm{Cu}_{26.4} \mathrm{Zn}_{21.6} \mathrm{~V}_{11.4} \mathrm{Al}_{40}$ & 95.10 \\
\hline
\end{tabular}




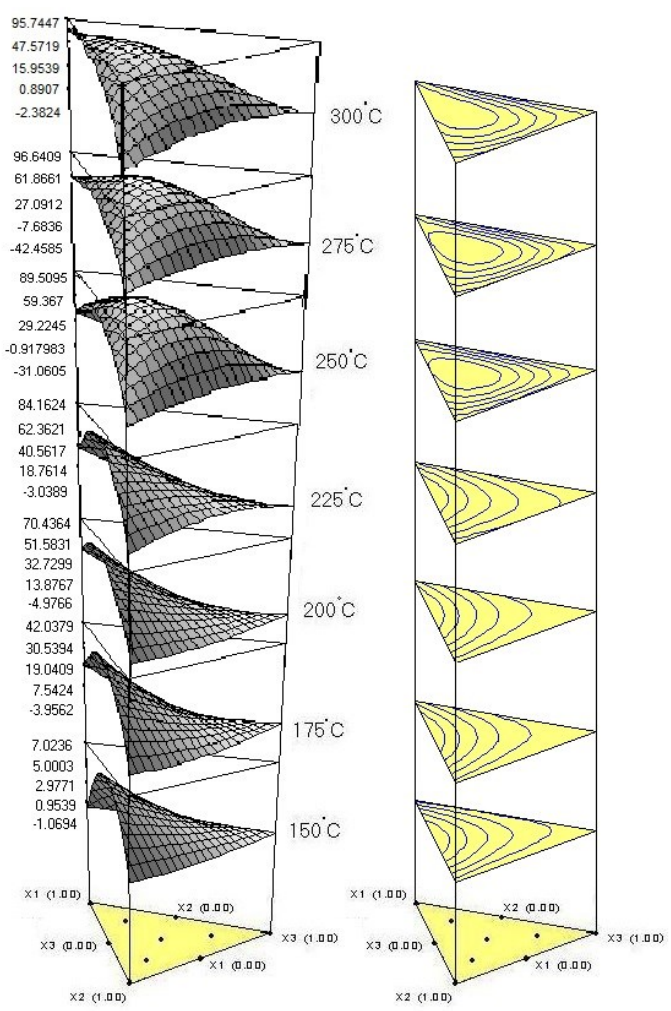

Fig. 11: Response surface of hydrogen yield against catalyst metal mass fraction of cuprum, zinc and vanadium, $\mathrm{X} 1, \mathrm{X} 2$ and $\mathrm{X} 3$, respectively, at various SRM reaction temperatures.

\subsubsection{Autothermal Reforming of Methanol (ATRM)}

The hydrogen yield was plotted against temperatures of ATRM reaction as shown in Fig. 12. Similar to the SRM result, the reference catalyst, $\mathrm{Cu}_{30} \mathrm{Zn}_{30} \mathrm{Al}_{40}$, also exhibits high activity from $150{ }^{\circ} \mathrm{C}$ to $225^{\circ} \mathrm{C}$ and from $250{ }^{\circ} \mathrm{C}$ to $300{ }^{\circ} \mathrm{C}$, the reaction yields of the catalysts promoted with vanadium that had an amorphous string were gradually dominant.

The response surface plot in Fig. 13 is between hydrogen yield and catalyst compositions at different temperatures. The optimum composition apparently changed with the elevation of reaction temperature. Initially, the peak appears at the $\mathrm{Cu}-\mathrm{Zn}-\mathrm{Al}$ catalyst. This peak moves towards the region of the catalyst composed of vanadia and it is sustained until $300{ }^{\circ} \mathrm{C}$. Optimum catalyst compositions in Fig. 13 at the respective reaction temperatures are summarised in Table 2. The Scheffe model was used to fit the data and the significance of their fitness were confirmed by the ANOVA analyses.

Table 2: Optimum mixture of catalysts in ATRM

\begin{tabular}{clc}
\hline Reaction Temperature $\left({ }^{\circ} \mathbf{C}\right)$ & Catalyst & Hydrogen Yield (\%) \\
\hline 150 & $\mathrm{Cu}_{31.2} \mathrm{Zn}_{28.8} \mathrm{Al}_{40}$ & 0.24 \\
175 & $\mathrm{Cu}_{33.6} \mathrm{Zn}_{25.8} \mathrm{~V}_{0.6} \mathrm{Al}_{40}$ & 10.01 \\
200 & $\mathrm{Cu}_{42.6} \mathrm{Zn}_{17.4} \mathrm{Al}_{40}$ & 46.96 \\
225 & $\mathrm{Cu}_{46.2} \mathrm{Zn}_{13.8} \mathrm{Al}_{40}$ & 74.22 \\
250 & $\mathrm{Cu}_{27.0} \mathrm{Zn}_{23.4} \mathrm{~V}_{9.6} \mathrm{Al}_{40}$ & 91.22 \\
275 & $\mathrm{Cu}_{31.8} \mathrm{Zn}_{19.8} \mathrm{~V}_{8.4} \mathrm{Al}_{40}$ & 95.35
\end{tabular}




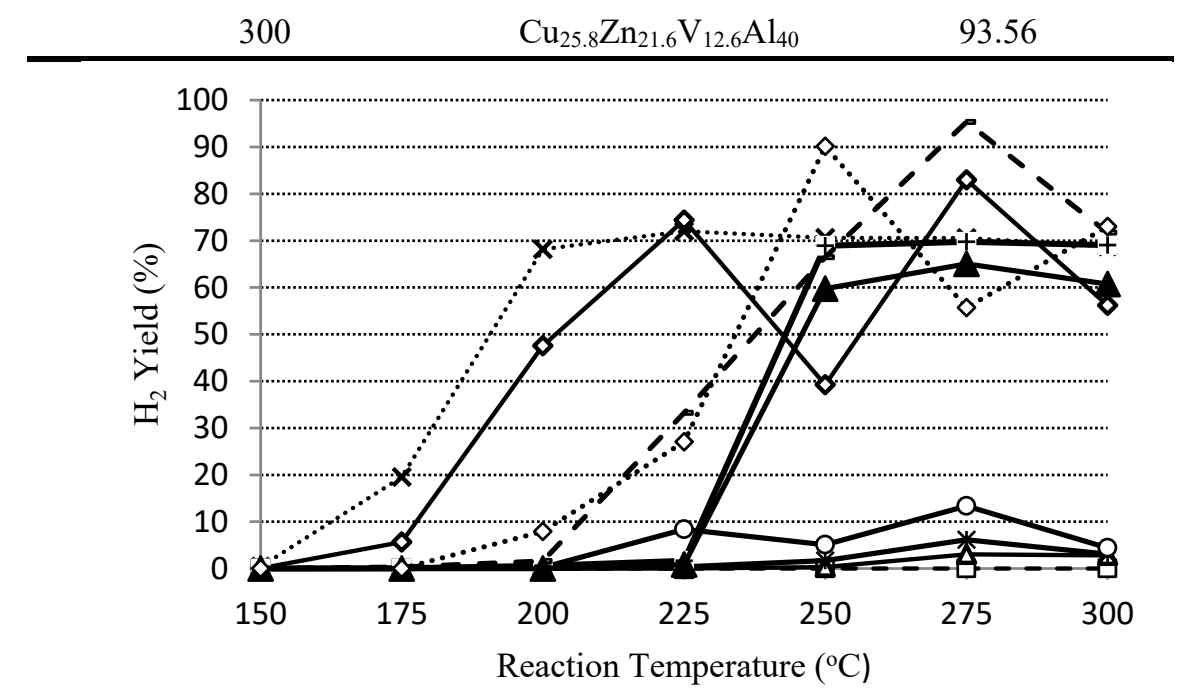

$$
\begin{aligned}
& \multimap \mathrm{Cu}_{60} \mathrm{Al}_{40} \quad \text { - } \leadsto-\mathrm{Zn}_{60} \mathrm{Al}_{40} \\
& \triangle \mathrm{V}_{60} \mathrm{Al}_{40} \quad \text {......... } \mathrm{Cu}_{30} \mathrm{Zn}_{30} \mathrm{Al}_{40} \\
& \text { *- } \mathrm{Cu}_{30} \mathrm{~V}_{30} \mathrm{Al}_{40} \quad-\quad-\mathrm{Zn}_{30} \mathrm{~V}_{30} \mathrm{Al}_{40} \text { " } \\
& \text {-+- } \mathrm{Cu}_{40} \mathrm{Zn}_{10} \mathrm{~V}_{10} \mathrm{Al}_{40} \quad---\mathrm{Cu}_{10} \mathrm{Zn}_{40} \mathrm{~V}_{40} \mathrm{Al}_{40} \\
& \longrightarrow \mathrm{Cu}_{10} \mathrm{Zn}_{10} \mathrm{~V}_{40} \mathrm{Al}_{40}{ }^{\bullet} \quad \cdots \diamond \cdots \mathrm{Cu}_{20} \mathrm{Zn}_{20} \mathrm{~V}_{20} \mathrm{Al}_{40} \text { }
\end{aligned}
$$

Fig. 12: Hydrogen yield versus reaction temperature at steady state for autothermal reforming of methanol. The catalyst legends added with superscript to denote having an amorphous structure.

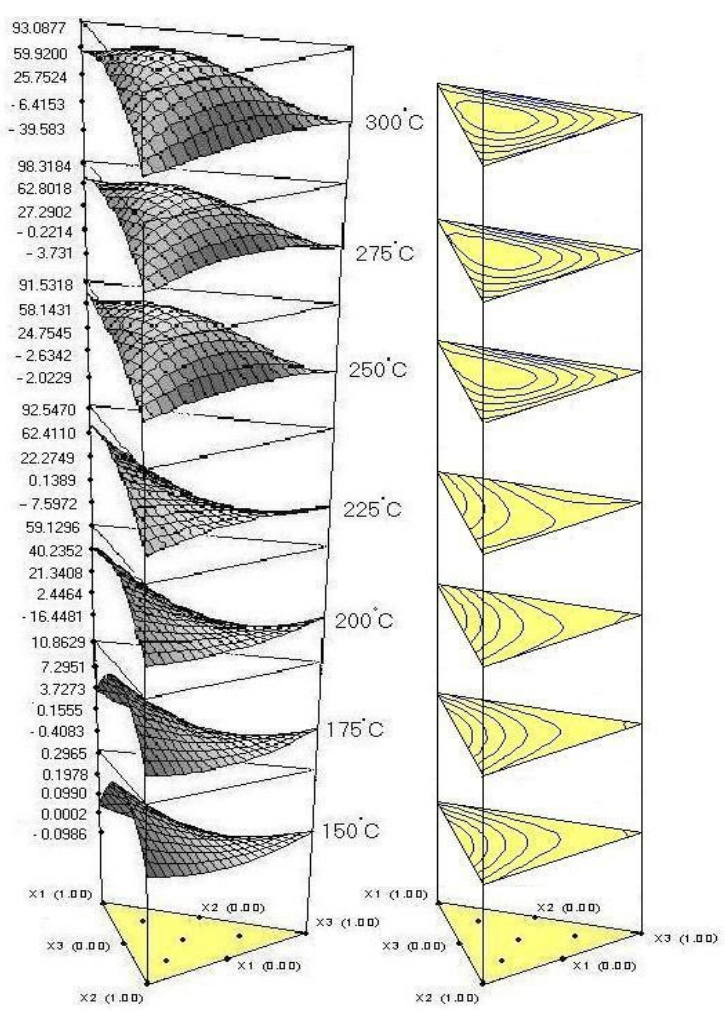

Fig. 13: Response surface of hydrogen yield against catalyst metal mass fraction of cuprum, zinc, and vanadium, X1, X2 and X3, respectively, 
at various ATRM reaction temperatures.

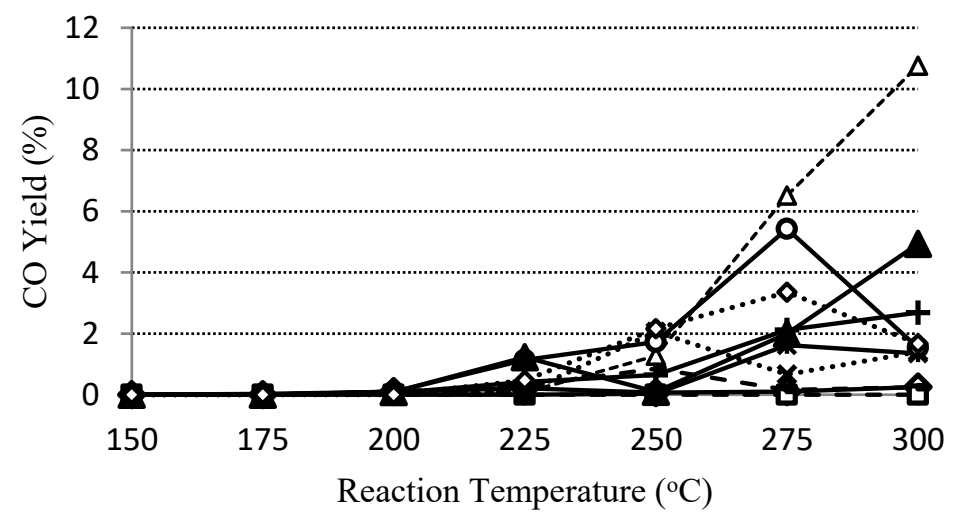

$$
\begin{aligned}
& \smile \mathrm{Cu}_{60} \mathrm{Al}_{40} \quad \text { - }-\mathrm{Zn}_{60} \mathrm{Al}_{40} \\
& \text {-- } \Delta \text {-.. } \mathrm{V}_{60} \mathrm{Al}_{40} \quad \text {........ } \mathrm{Cu}_{30} \mathrm{Zn}_{30} \mathrm{Al}_{40} \\
& \rightarrow \mathrm{Cu}_{30} \mathrm{~V}_{30} \mathrm{Al}_{40} \quad \text { - }-\mathrm{Zn}_{30} \mathrm{~V}_{30} \mathrm{Al}_{40} \text { " } \\
& \longrightarrow \mathrm{Cu}_{40} \mathrm{Zn}_{10} \mathrm{~V}_{10} \mathrm{Al}_{40} \ldots \mathrm{Cu}_{10} \mathrm{Zn}_{40} \mathrm{~V}_{10} \mathrm{Al}_{40} \\
& \longrightarrow-\mathrm{Cu}_{10} \mathrm{Zn}_{10} \mathrm{~V}_{40} \mathrm{Al}_{40} \bullet \cdots \diamond \mathrm{Cu}_{20} \mathrm{Zn}_{20} \mathrm{~V}_{20} \mathrm{Al}_{40}
\end{aligned}
$$

Fig. 14: CO yield as a function of reaction temperatures for various catalysts for autothermal reforming of methanol. The catalyst legends added with superscript $\bullet$ to denote having an amorphous structure.

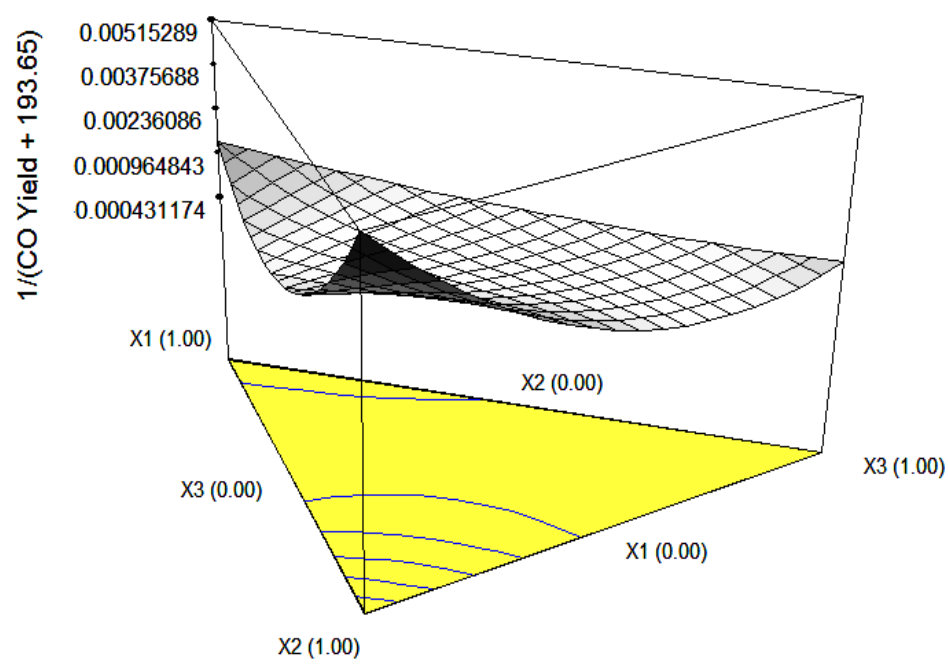

Fig. 15: Reciprocal CO yield with a constant of 193.65 as a function of catalyst metal composition, the best fitted model.

\section{CONCLUSION REMARKS}

Promoting vanadium in the co-precipitated $\mathrm{Cu}-\mathrm{Zn}-\mathrm{Al}$ catalyst in this study created a new structure that was probably AS, while the better yield of hydrogen was sought in the methanol reforming reaction. The characterization of prepared catalysts supports this suggestion. From the XRD and SEM-EDX results, the combination of V and $\mathrm{Zn}$ formed the 
AS besides crystals where their structure was reduced to uniform rods in the catalyst of $\mathrm{Cu}$ $\mathrm{Zn}-\mathrm{Al}$ mixtures. Reducibility of the catalyst containing high AS under TPR is relatively low, implying that this structure did not enhance the reaction rate. The effect of the AS was finally observed in the reaction tests. Optimum yield of hydrogen was, however, shown by the catalyst with high cuprum content at temperatures lower than $150{ }^{\circ} \mathrm{C}$ where the AS did not clearly appear $\left(\mathrm{Cu}_{34} \mathrm{Zn}_{12} \mathrm{~V}_{14} \mathrm{Al}_{40}\right)$. Interestingly, vanadia-promoted catalysts with the significant presence of AS showed the maximum hydrogen yield and low $\mathrm{CO}$ formation at temperatures higher than $225{ }^{\circ} \mathrm{C}$ in the SRM and ATRM reactions. The reaction results therefore suggest that the AS could have prevented the catalysts at high temperature from deactivation.

\section{ACKNOWLEDGEMENT}

The author wishes to thank the Ministry of Science, Technology and Innovation (MOSTI), Malaysia for the National Science Fellowship awarded to MSM, the IRPA 02-02-02-0004PR0023/11-09 grant awarded to Prof. Ir. Dr. Zahira Yaakob and Prof. Ir. Dr. Wan Ramli Wan Daud and RDU140138, FRGS 2014-1 grant awarded to Dr Vo Nguyen Dai Viet.

\section{REFERENCES}

[1] Yong-Feng, L., D. Xin-Fa, and L. Wei-Ming (2004) Effects of $\mathrm{ZrO}_{2}$-promoter on catalytic performance of $\mathrm{CuZnAlO}$ catalysts for production of hydrogen by steam reforming of methanol. International Journal of Hydrogen Energy, 29 1617-1621.

[2] Dahl, P.J., T.S. Christensen, S. Winter-Madsen, and S.M. King (2014). Proven autothermal reforming technology for modern large-scale methanol plants. in Nitrogen + Syngas 2014 International Conference \& Exhibition. Paris.

[3] Huang, X., L. Ma, and M.S. Wainwright (2004) The influence of Cr, Zn and Co additives on the performance of skeletal cuprum catalysts for methanol synthesis and related reactions. Applied Catalysis A: General, 257 (2): 235-243.

[4] Reuse, P., A. Renken, K. Haas-Santo, O. Görke, and K. Schubert (2004) Hydrogen production for fuel cell application in an autothermal micro-channel reactor. Chemical Engineering Journal, 101 133-141.

[5] Courtine, P. and E. Bordes (1997) Mode of arrangement of components in mixed vanadia catalyst and its bearing for oxidation catalysis. Applied Catalysis A: General, 157 (1-2): 45-65.

[6] Park, J.E., S.-D. Yim, C.S. Kim, and E.D. Park (2014) Steam reforming of methanol over $\mathrm{Cu} / \mathrm{ZnO} / \mathrm{ZrO} 2 / \mathrm{A} 12 \mathrm{O} 3$ catalyst. International Journal of Hydrogen Energy, 39 (22): 11517-11527.

[7] Ma, Y., G. Guan, C. Shi, A. Zhu, X. Hao, Z. Wang, K. Kusakabe, and A. Abudula (2014) Low-temperature steam reforming of methanol to produce hydrogen over various metal-doped molybdenum carbide catalysts. International Journal of Hydrogen Energy, 39 (1): 258-266.

[8] Agrell, J., H. Birgersson, M. Boutonnet, I. Melian-Cabrera, R.M. Navarro, and J.L.G. Fierro (2003) Production of hydrogen from methanol over $\mathrm{Cu} / \mathrm{ZnO}$ catalysts promoted by $\mathrm{ZrO}_{2}$ and $\mathrm{Al}_{2} \mathrm{O}_{3}$. Journal of Catalysis, 219 389-403.

[9] Lima, A.A.G., M. Nele, E.L. Moreno, and H.M.C. Andrade (1998) Composition effects on the activity of $\mathrm{Cu}-\mathrm{ZnO}-\mathrm{Al} 2 \mathrm{O} 3$ based catalysts for the water gas shift reaction: A statistical approach. Applied Catalysis A: General, 171 (1): 31-43. 
[10] Sekizawa, K., S.-i. Yano, K. Eguchi, and H. Arai (1998) Selective removal of CO in methanol reformed gas over $\mathrm{Cu}$-supported mixed metal oxides. Applied Catalysis A: General, 169 (2): 291-297.

[11] Begum, M., Preparation and Characterization of Cu-Al Catalysts for The SteamMethanol Reforming Reaction, in Dep of Chemical and Process Engineering. 2000, UKM: Selangor.

[12] Prime13. Altamira Instruments: The First Name in Custom Reactor Systems. 2010 2nd February 2015; Available: http://www.altamirainstruments.com/.

[13] Agrell, J., G. Germani, S.G. Järås, and M. Boutonnet (2002) Production of hydrogen by partial oxidation of methanol over $\mathrm{ZnO}$-supported palladium catalysts prepared by microemulsion technique. Applied Catalysis A: General, 6383 1-13.

[14] Agrell, J., M. Boutonnet, and J.L.G. Fierro (2003) Production of hydrogen from methanol over binary $\mathrm{Cu} / \mathrm{ZnO}$ catalysts: Part II. Catalytic activity and reaction pathways. Applied Catalysis A: General, 253 (1): 213-223.

[15] Richardson, J.T., Principles of Catalyst Development, ed. 1. 1989, New York: Plenum Press.

[16] Idem, R.O. and N.N. Bakhshi (1996) Kinetic modeling of the production of hydrogen from the methanol-steam reforming process over Mn-promoted coprecipitated $\mathrm{Cu}-\mathrm{Al}$ catalyst. Chemical Engineering Science, 51 (14): 3697-3708.

[17] Reddy, E.P. and R.S. Varma (2004) Preparation, characterization, and activity of A12O3-supported V2O5 catalysts. Journal of Catalysis, 221 (1): 93-101.

[18] Lindström, B., L.J. Pettersson, and P.G. Menon (2002) Activity and characterization of $\mathrm{Cu} / \mathrm{Zn}, \mathrm{Cu} / \mathrm{Cr}$ and $\mathrm{Cu} / \mathrm{Zr}$ on $\gamma$-alumina for methanol reforming for fuel cell vehicles. Applied Catalysis A: General, 234 111-125.

[19] Lindström, B., J. Agrell, and L.J. Pettersson (2002) Combined methanol reforming for hydrogen generation over monolithic catalysts. Chemical Engineering Journal, 4053 1-11.

[20] Inumaru, K., M. Misono, and T. Okuhara (1997) Structure and catalysis of vanadium oxide overlayers on oxide supports. Applied Catalysis A: General, 149 (1): 133-149.

[21] Botto, I.L., M.B. Vassallo, E.J. Baran, and G. Minelli (1997) IR spectra of $\mathrm{VO}_{2}$ and $\mathrm{V}_{2} \mathrm{O}_{3}$. Materials Chemistry and Physics, 50 267-270.

[22] Choi, Y. and H.G. Stenger (2002) Fuel cell grade hydrogen from methanol on a commercial $\mathrm{Cu} / \mathrm{ZnO} / \mathrm{Al}_{2} \mathrm{O}_{3}$ catalyst. Applied Catalysis B: Environmental, 38 259269. 